\title{
The impact of employing the realistic model on the academic achievement of history subject and the development of critical thinking among the literary fifth-grade female students
}

\author{
Lect. Iman Muhammad Khudair ${ }^{1}$ and Prof.Dr. Saad Ali Zayer ${ }^{2}$ \\ ${ }^{1}$ Al-Mustansiriya University - College of Education. \\ ${ }^{2}$ University of Baghdad - College of Education - IbnRushd.
}

\begin{abstract}
The research aims at studying the impact of employing the realistic model in the academic achievement of history subject and the development of critical thinking among fifth-grade literary female students. The research was applied to the research sample adopting the experimental approach with the post-test of achievement, pre and posttest for critical thinking, where the sample was divided into an experimental group (30 female students) using the realistic model and a control group (30 female students) using the standard method. After conducting equivalence between the two groups in (chronological age, intelligence, the criterion of pre-critical thinking, and the grades of students in the history subject for the fourth grade of middle school) the scientific material represented in the first and second semesters of the subject to be taught to fifth-grade literary students at the Ministry of Education was determined.The behavioral purposes were extracted, preparing therequired plans, and students were taught according to their steps.After applying the experiment and applying the two research tools, the following results were reached:
\end{abstract}

1- There is a statistically significant difference at the level of (0.05) in achievement in favor of the experimental group.

2- There is a difference of statistical significance at the level (0.05) between the mean scores of the two groups in developing critical thinking in favor of the experimental group.

Article Received: 10 August 2020, Revised: 25 October 2020, Accepted: 18 November 2020

\section{Introduction}

Understanding science and its processes contributes to the development of thinking in a creative and critical manner and solving problems. Hence, interest in scientific knowledge in general has increased. Therefore, education specialists emphasize that teaching history is not just the transfer of knowledge to students, but rather the process of building their knowledge, integrating their growth, and teaching them how they learn and think in a scientific way critically, not how to preserve information without understanding and applying it. Successful teaching lies in choosing the appropriate learning theory or models to guide classroom practices. Vigo Tesky's theory of social cultural development emphasized the concept of new teaching based on a social construct. (Abd al-Salam, 148,2006)

\section{Research problem:}

The idea of research crystallized through identifying the problems that students and teachers suffer from alike in the low level of historical achievement and how to develop higher levels of thinking for students. After diagnosing the strengths and weaknesses in their learning of historical concepts and upon our study and our acquaintance with modern theories and their educational models, including the Vygotsky's constructivist knowledge theory, specifically the realistic model and the positive results reached by some studies in improving students' achievement performance and its effective impact on some variables.

Accordingly, the researchers decided to apply the realistic three-stage model based on constructive knowledge and the generation of scientific ideas and concepts, which may contribute to raising the level of historical academic achievement of students and the development of their critical thinking. That's because of the students' previous experiences and historical scientific concepts that can be organized and employed to generate new information as solutions to problems, an understanding and awareness of educational situations, then forming critical reflective perceptions to assess the causes and find relationships between them in order to reach the results. 


\section{Research importance:}

(Al-Khaliliand et al. 1996) state that educators consider that creative teaching relies on constructive models, and teaching operational strategies that emphasize the active and student's effective role in education within groups or teams and the actual intellectual participation in making learning meaningful based on understanding. (Al-Khalili, 1996, 438)

(Al-Zand 2004) identified the importance of constructivist theory in the field of learning as follows:

1. Activating the educational external assistance required by the learner

2. Activity and self-organization of the learner by discovering mistakes and correcting them.

3. Developing the learner's thinking. (AzZand, 149,2004)

It can be concluded that successful teaching and historical achievement improvement by adopting the realistic model is done by addressing the following factors:

First: Analyzing the reality before carrying out the lesson, as the teacher must answer the following questions:

What is the nature of the subject or scientific content that will be studied?

\section{Second: planning for teaching:}

This component focuses on preparing a teaching plan

\section{Third: implementation of the lesson:}

This component focuses on what is really going on in the classroom.

One of the most prominent teaching models emanating from the constructivist theory is the realistic model that employs constructivist philosophy and the principles of teaching science and improving teaching in various realistic conditions represented by the nature of the subject matter, the characteristics of students, the teacher, the educational institution and the local environment.

The importance of this model comes through the following:

1 - Building the learner's cognitive structure in his own way by interacting with natural phenomena with others around them.

2- Creating an educational environment with specific characteristics, as it is based on a set of practices that shape school life as a whole through students' interaction with their teachers and their interaction among themselves to acquire and employ knowledge in their lives. (Al-Wahar, 2003, p.94)

Among the studies that indicated the effectiveness of the realistic model was the study of Al-Falih (2003), the results of which showed improvement in students 'achievement in science and correcting alternative perceptions of some concepts.

(Abu Jadu\& Muhammad, 2007) stress that what characterizes today society is the trend towards change, which requires the developing students' abilities to complete the processes of analysis and evaluation of information in addition to working to criticize it. It is known as a critical thinking of great importance in education based on empowering students with basic teaching and learning skills and strategies for critical thinking by encouraging the spirit of inquiry, research, inquiry and nonacceptance of facts without investigation and exploration leading to broadening students' knowledge horizons and pushing them towards broader scientific fields and enriching their mental structures And increase their quality learning. (Abu Jadu and Muhammad, 2007, 225)

(Al-Atoum, 2004) shows the importance of teaching critical thinking as a skill for students to make them achieve better marks in performing tests, less reliant on teachers and textbooks, and tend to depend on themselves in the learning process. They would be more able to build knowledge by selfreliance, and they change the structures in society that restrict certain groups of people. He adds that the critical thinker is interested in knowledge and enjoys the ability to read, based on logic, flexible and broadminded, and committed to discipline in dealing with multiple issues and choosing standards. It shows a high focus in the investigation process and searching for accurate results. To create critical thinkers, it is necessary to combine the development of critical thinking skills and nurture those tendencies that are the basis of a rational and democratic society. (Atoum, 2004, 22)

The approaches and methods of teaching are not the same in every age and in every society. Rather, they are the product of certain social conditions and needs. They change according to educational interests and community requirements, and they change as the sources of knowledge multiply and diversify. (Ministry of Education, 1998, 218). Therefore, in order to improve the effectiveness of the educational process, the teacher can develop many different tools and models adopted in improving educational achievement. (Bakhsh, 2008, 108). Through the aforementioned, the importance of 
the current research can be determined in the following points:

1. The importance of adopting constructive cognitive models based on student's interaction with educational situations and acquiring new information by linking it to previous experiences and paying attention to meaningful learning.

2. The importance of language and communication between the teacher and his students, and between the students themselves.

3. Attention to developing higher levels of thinking among students, including critical thinking, to build a generation of thinkers keeping pace with modern scientific and technological advances.

4. The science of history is applied is a science that depends on experience and evidence, and specifically in the preparatory stage, which depends on the theoretical and practical side in teaching its students.

\section{Research objectives:}

1 - The effect of using the realistic model on the achievement of the history course among the fifthgrade literary female students.

2- The effect of using the realistic model on developing critical thinking among female literary fifth grade female students.

\section{Research hypotheses:}

For the purpose of verifying the two research objectives, the following two null hypotheses were formulated:

1- There is no statistically significant difference at the level of significance $(0.05)$ between the average scores of the experimental group female students who study according to the steps of the realistic model, and the average scores of the control group female students who study according to the usual method of achievement.

2- There is no statistically significant difference at the level of significance $(0.05)$ between the average scores of the experimental group female students who study according to the steps of the realistic model, and the average scores of the control group female students who study according to the usual method of developing critical thinking.

\section{Research limits:}

1- Fifth-grade literary female students in the day schools of Baghdad Education, Rusafa II.

2- The first semester of the academic year (2019, 2020).
3- The first and second semesters of the history course to be taught for fifth-grade literary students.

\section{Defining terms:}

\section{Realistic model:}

(Al-Khalili and et al.) defined it"employing the requirements of constructivist philosophy and the principles of science teaching in various realistic circumstances, represented by the nature of the subject matter and the characteristics of students, educators and teachers, consisting of three components: reality analysis, planning, implementation. (Al-Khalili and et al. 1996, 126)

Procedural definition of a realistic model: A model that includes three successive phases, namely, analyzing the reality of the lesson and the environment, planning the lesson, the implementation process that includes the activities and duties that the experimental group students undertake.

\section{Achievement:}

(Abu Jadu) defined it as the outcome of what the learner learns after a period of time has passed, and it can be measured by the degree that he obtains by the achievement test. (Abu Jadoo, 469, 2000). Shehata and Zainabdefined it as a set of knowledge and skills obtained and developed during the course of study subjects, as indicated by test scores. (Shehata and Zainab, 89, 2003)

Procedural definition of achievement: It is the set of scientific information obtained by the female students, as a result of their study of the history course, where it is measured by the total score of the achievement test prepared for the purposes of the current research.

\section{Critical thinking:}

(Abu Jadu and Muhammad) defined critical thinking as: reflective, inferential, self-evaluative thinking that includes a set of interconnected cognitive strategies and processes such as interpretation, analysis, evaluation and conclusion, with the aim of examining opinions, beliefs, evidence, proofs, concepts and allegations that are based upon when issuing a particular judgment, or solving a problem, or making a decision, while $\mathrm{t}$ aking the viewpoints of others. (Abu Jadu and Muhammad, 231, 2007)

Attia defined it as "revealing the defects and merits of something vague or analyzing it, as it includes higher levels of mental perception represented by analysis, synthesis and evaluation according to Bloom's classification. (Attia, 132, 2010) 
The procedural definition of critical thinking: It is the set of scores that female students obtain in the test prepared for this purpose to measure skills of assumptions knowledge, interpretation, evaluation of arguments, deduction, and reproduction.

The theoretical basis of the research:

\section{Realistic model components:}

A realistic model for science education consists of three components: reality analysis, teaching planning and implementation.

\section{First: Reality analysis}

The reality is analyzed before carrying out teaching, for the teacher must answer the following questions:

- What is the nature of the subject or scientific content that will be studied?

- What is the ability and capabilities of the teacher to teach this topic or content?

- What is the reality of students for whom this topic or content will be taught?

- What is the reality of the school in which the subject or content will be taught?

- What is the reality of the environment or society in which the learner lives?

\section{Second: planning for teaching}

This component focuses on preparing a teaching plan which consists of several components, namely:

- determining the entry (incentive configuration)

- Determining the principles and generalizations that will be taught.

- Determining the experiences and activities that students will carry out.

- Determining the thinking-provoking questions that will be raised for the dialogue.

- Determining the aspects of linking scientific knowledge with the student's life and environment and with faith in God Almighty.

\section{Third: the implementation of the lesson}

This component focuses on what is actually going on in the classroom, as it consists of several sequential steps, namely:

\section{1- Entrance}

The lesson is done through motivational preparation, stimulating students' curiosity, and participating in activities.
2- Treatment of misconceptions (wrong understanding) of students. This is done through three stages:

- The stage of dissatisfaction with a misunderstanding.

- The stage of accepting a sound scientific understanding.

.The stage of adopting a sound scientific understanding.

\section{3- Implementing activities}

The students are divided into heterogeneous cooperating groups whose members number from four to five, or according to the place of work. Each group has a head who organizes the work, and the teacher has the right to ask any individual in the group to give the answer to this group. Any mistake he commits is counted as the whole group, and the groups are rewarded for cooperation among its members by increasing each student in the group by five points in any test that the teacher takes in class. That is, the groups are cooperating within the same group and competing to win, and then papers are distributed that include the thinking-provoking questions.

\section{Dialogue session}

As the group discussion takes place as the teacher leads the dialogue towards the concept or principle to be learned.

\section{5- Organization}

The direct teaching is carried out by the teacher, as he organizes the students' conclusions and formulates the correct concepts, principles and laws.

\section{1- Application}

The results of the lesson are linked to the student's life or to the new practical situations, in addition to reminding of the greatness of the Creator, May He be glorified and exalted, for example, either by citing the noble verses, or by mentioning by the teacher by saying Glory be to Allah, What is the greatest power and accuracy of Allah ... etc.

\section{2- Closure}

The teacher will conclude his work in the lesson by mentioning the main points that were covered in it. (Al-Khalili and et al. 1996, 459-463) (Ibrahim, 2004, 854).

\section{Previous studies}

Al-Falih's study (2003): 
The study aimed to know the effectiveness of the realistic model in developing academic achievement and science processes and modifying understanding and error and the trend towards science among first grade intermediate students. The study was conducted in Riyadh where the sample consisted of 120 female students and the researcher prepared an achievement test (a multiple test), a process of science tests, building a measure of the trend towards science. The results showed the development of the experimental group over the control group students in the degrees of achievement, testing the science processes and the direction towards science. This is a result of the effectiveness of the realistic model in teaching. (Al-Falih, 2003, 94)

Abd al-Reda's and Batoul'sstudy (2006):

The study aimed to know the effect of using the realistic model to learn the acquisition of concepts on academic achievement and the development of scientific trends among students of the Teacher Education Institute / Al-Karkh / Training \& Rehabilitation Directorate. It was conducted in Baghdad, and the study sample consisted of (59) students. The researcher prepared an achievement test of the multiple and scale test type to measure scientific trends. The results showed the superiority of the experimental group that was studied according to the realistic model over the control group that studied in the usual way in terms of achievement test scores and degrees of the scientific trends scale. (Abd Al-Ridha and Batoul, 2006, 66-75)

Muhammad'sstudy (2009):

The study aimed to know the realistic model in modifying the understanding and error of the physical concepts of the second-grade female students and their academic achievement. The study was conducted in Babil / Iraq and the research sample consisted of (76) students. The researcher prepared an achievement test and a test of physical concepts, where the results showed the superiority of the experimental group that studied through the realistic model over the control group that studied in the usual way in achievement test scores and physical ones. This is an indication of the effectiveness of the realistic model. (Muhammad, 2009)

\section{Research procedures:}

\section{First: Experimental Design:}

It is a planning for the conditions and factors surrounding the phenomenon that we study in a specific way and observing what happens. It is a blueprint for how to implement the experiment. (Abd al-Rahman and Adnan, 2007, 487). The design of equivalent groups of partial control, with the experimental group and the control group, with the post-test for achievement and the pre and post test for critical thinking was chosen. As shown in the following chart:

\begin{tabular}{|c|c|c|c|c|c|}
\hline Group & Equivalence & Pre-test & $\begin{array}{c}\text { Independent } \\
\text { variables }\end{array}$ & $\begin{array}{c}\text { Dependent } \\
\text { variables }\end{array}$ & Post-test \\
\hline $\begin{array}{c}\text { Experiment } \\
\text { al }\end{array}$ & $-\begin{array}{c}\text { Age by month } \\
\text { Intelligence } \\
\text { thinking } \\
\text { Control }\end{array}$ & $\begin{array}{c}\text { Pre-critical } \\
\text { measurement } \\
\text { Last year grades }\end{array}$ & $\begin{array}{c}\text { Critical } \\
\text { thinking }\end{array}$ & Realistic model & $\begin{array}{c}\text { Developing } \\
\text { critical } \\
\text { thinking test }\end{array}$ \\
\hline
\end{tabular}

\section{Second: The research community and its sample:}

The research community was identified with fifthgrade literary female students in RusafaII Education Schools in Baghdad governorate, from which Badr Al-Kubra High School was intentionally chosen, which includes two divisions for the fifth grade literary to represent the research sample. Division (A) represents the experimental group, whereas the Division (B) represents the control group, and the number of two groups reached (60) female students, after excluding female students who had failed.

\section{Third: Equal Groups:}

In order to carry out the equivalence process between the two research groups, some variables that may affect the results of the research have been controlled, including: chronological age in months, intelligence, and students' scores in history for the previous year, and the criterion of critical pre-thinking. 
By adopting the arithmetic mean and standard deviation of the two research groups and applying the T-test to compare them, the results showed that there are no statistically significant differences between the two research groups.It indicatesthat they are statistically equivalent in all variables as shown in the following table:

\begin{tabular}{|c|c|c|c|c|c|c|c|c|}
\hline \multirow[t]{2}{*}{ Variables } & \multirow[t]{2}{*}{ Group } & \multirow{2}{*}{$\begin{array}{l}\text { No. } \\
\text { stude } \\
\text { nts }\end{array}$} & \multirow{2}{*}{$\begin{array}{l}\text { Arithmeti } \\
\text { c mean }\end{array}$} & \multirow{2}{*}{$\begin{array}{l}\text { Standar } \\
\text { d } \\
\text { deviatio } \\
\text { n }\end{array}$} & \multirow{2}{*}{$\begin{array}{l}\text { Degree } \\
\text { of } \\
\text { freedo } \\
\text { m }\end{array}$} & \multicolumn{2}{|c|}{ T-Value } & \multirow[t]{2}{*}{ Function level } \\
\hline & & & & & & Calculated & Tabular & \\
\hline Age & $\begin{array}{l}\text { Experimental } \\
\text { control }\end{array}$ & $\begin{array}{l}30 \\
30\end{array}$ & $\begin{array}{l}230.933 \\
231.633\end{array}$ & $\begin{array}{l}6.378 \\
8.260\end{array}$ & 58 & 0.367 & 2.000 & Non-functional \\
\hline $\begin{array}{l}\text { Intellige } \\
\text { nce }\end{array}$ & $\begin{array}{l}\text { Experimental } \\
\text { control }\end{array}$ & $\begin{array}{l}30 \\
30\end{array}$ & $\begin{array}{l}46.200 \\
45.466\end{array}$ & $\begin{array}{l}27.980 \\
25.621\end{array}$ & 58 & 0.106 & 2.000 & Non-functional \\
\hline $\begin{array}{l}\text { Last } \\
\text { year } \\
\text { grades }\end{array}$ & $\begin{array}{l}\text { Experimental } \\
\text { control }\end{array}$ & $\begin{array}{l}30 \\
30\end{array}$ & $\begin{array}{l}67.133 \\
70.466\end{array}$ & $\begin{array}{l}9.655 \\
12.311\end{array}$ & 58 & 1.167 & 2.000 & Non-functional \\
\hline $\begin{array}{l}\text { Pre- } \\
\text { critical } \\
\text { thinking }\end{array}$ & $\begin{array}{l}\text { Experimental } \\
\text { control }\end{array}$ & $\begin{array}{l}30 \\
30\end{array}$ & $\begin{array}{l}27,966 \\
26,833\end{array}$ & $\begin{array}{l}8,356 \\
7,332\end{array}$ & 58 & 1.288 & 2.000 & Non-functional \\
\hline
\end{tabular}

\section{Fourth: research requirements:}

The scientific subject was determined according to the curriculum in the first and second semesters of the first semester of the year (20192020), and the behavioral objectives of the prescribed academic subject were formulated, amounting to (87) behavioral purposes. Then distributing them on Bloom's six cognitive levels represented by (remembering, comprehension, application, analysis, application, and evaluation) in addition to preparing 10 teaching plans according to research variables on the basis of the realistic model and the usual method.

\section{Fifth: research tools:}

The researchers adopted two tools to measure the extent of achievement of results and according to the specific research objectives. The first tool is an achievement test consisting of (20) test items distributed according to the content and levels of cognitive objectives by preparing the appropriate test map for it. The paragraphs of the multiple choice type were determined, and its apparent validity was extracted by adopting Cooper's equation of $(80 \%)$ for the experts' opinions and specialists' in education and teaching methods, as well as the validation of the content through the preparation of the test map. A preliminary application of the exploratory experiment in order to determine the ambiguities and determine the time required for the test was (60 minutes). As for the second exploratory experiment to conduct statistical analysis of the items of the achievement test by extracting the difficulty factors, ranging between (0.41) and (0.62), which is considered good and acceptable. As for the strength of the distinction, it was between $(0.51)$ and $(0.73)$, which is considered good and acceptable as well within the specified range. The effectiveness of the wrong alternatives was revealed, and the results were of a negative value, so the alternatives were effective. To extract the stability of the achievement test, the AlphaCronbach equation was adopted, with a value of (0.84), and it is considered a good stability coefficient. (Odeh and Hebron, 1988, 146)

As for the second tool, it was a measurement of critical thinking prepared by (Al-Khazraji, 2011) and consisting of five areas: knowledge of assumptions, interpretation, arguments evaluation, deduction and conclusion, in addition to three alternatives for each. By applying the initial exploratory experiment, the time required for the answer was calculated and it was (70) minutes, and the second exploratory to analyze the paragraphs statistically. The validity of structuring the scale paragraphs was found by finding the relationship for each paragraph with the total score by adopting the Pearson equation, whose value was between (082) ) and (0.88), which are good correlation coefficients. By using the special equation to extract the $\mathrm{T}$ value, it is found that the calculated $\mathrm{T}$ value is higher than the tabular $\mathrm{T}$ value for all the paragraphs, i.e. verifies the validity of the construction of the scale. As well as calculating the preliminary strength of its paragraphs by adopting the T-test for two independent equal samples. The researchers found that the calculated $\mathrm{T}$ 
value is higher than the tabular, meaning there is a difference between the upper and lower group scores and thus the scale paragraphs are considered good. In addition to calculating the reliability of the scale of critical thinking by adopting the Alpha-Cronbach equation, which is $(0,79)$. The reliability coefficient is good and acceptable. (Al-Nabhan, 2004, 240)

\section{Sixth: Statistical Means:}

The T-test was adopted for two equal independent samples, the difficulty coefficient equation, the strength of discrimination equation, the false alternatives efficacy equation, the Alpha-Cronbach equation, and the T-test for two correlated samples.

\section{Results of the research:}

After applying the two research tools, achievement test and critical thinking, according to the specific objectives and hypotheses of the research, the following results were reached:
First: For the purpose of testing the first research hypothesis, the arithmetic mean and the standard deviation of the scores of the two research groups were found in the achievement test, and by adopting the T-test for two independent samples. The results showed that the calculated $\mathrm{T}$ value (2.99) is greater than the table value (2.00), at a level of significance (0.05) and a degree of freedom (58). That is, it is statistically significant and in favor of the experimental group students who studied according to the realistic model, superiority over the control group students who studied according to the normal method in the achievement test, and for this the first null hypothesis of the research was rejected. This can be illustrated in the following table:

T-Value of the achievement test of the experimental and control groups

\begin{tabular}{|c|c|c|c|c|c|c|c|}
\hline \multirow[t]{2}{*}{ Group } & \multirow{2}{*}{$\begin{array}{l}\text { No. } \\
\text { students }\end{array}$} & \multirow{2}{*}{$\begin{array}{l}\text { Arithmetic } \\
\text { mean }\end{array}$} & \multirow{2}{*}{$\begin{array}{l}\text { Standard } \\
\text { deviation }\end{array}$} & \multirow{2}{*}{$\begin{array}{l}\text { Degree } \\
\text { of } \\
\text { freedom }\end{array}$} & \multicolumn{2}{|l|}{ T-Value } & \multirow{2}{*}{$\begin{array}{l}\text { Function } \\
\text { level }\end{array}$} \\
\hline & & & & & Tabular & Calculated & \\
\hline Experimental & 30 & 15,20 & 3,35 & 58 & 2,989 & 2,00 & $\begin{array}{l}\text { Functional } \\
\text { for the } \\
\text { experimen } \\
\text { tal group }\end{array}$ \\
\hline Control & 30 & 12,86 & 4,01 & & & & \\
\hline
\end{tabular}

Second: For the purpose of testing the second research hypothesis, the difference in the students 'scores was found for the Critical Thinking Scale, then the arithmetic mean and the standard deviation of the score difference of the two research groups. By adopting the $\mathrm{T}$ test for two independent samples, the results showed that the calculated $\mathrm{T}$ value $(6,140)$ is greater than the tabular $(2,00)$ at the level of significance $(0.05)$ and the degree of freedom
(58). That is, it is a statistical function and in favor of the experimental group students who studied according to the realistic model, superiority over the control group students who studied according to the usual method of developing critical thinking. This can be illustrated in the following table:

The $\mathrm{T}$ value of the difference in the pre and post test scores of the Critical Thinking Development Scale for the experimental and control groups

\begin{tabular}{|c|c|c|c|c|c|c|c|}
\hline \multirow[t]{2}{*}{ Group } & \multirow{2}{*}{$\begin{array}{c}\text { No. } \\
\text { students }\end{array}$} & \multirow{2}{*}{$\begin{array}{l}\text { Arithmetic } \\
\text { mean }\end{array}$} & \multirow{2}{*}{$\begin{array}{l}\text { Standard } \\
\text { deviation }\end{array}$} & \multirow{2}{*}{$\begin{array}{l}\text { Degree } \\
\text { of } \\
\text { freedom }\end{array}$} & \multicolumn{2}{|l|}{ T-Value } & \multirow{2}{*}{$\begin{array}{l}\text { Function } \\
\text { level }\end{array}$} \\
\hline & & & & & Tabular & Calculated & \\
\hline Experimental & 30 & 69,9000 & 9,7215 & 58 & 6,140 & 2,00 & $\begin{array}{l}\text { Functional } \\
\text { for } \\
\text { experimen } \\
\text { tal group }\end{array}$ \\
\hline Control & 30 & 56,000 & 7,6968 & & & & \\
\hline
\end{tabular}


T-Value of the difference between the pre \&post-tests of critical thinking development of the experimental group

\begin{tabular}{|c|c|c|c|c|c|c|c|}
\hline \multirow[b]{2}{*}{ Test } & \multirow{2}{*}{$\begin{array}{c}\text { No. } \\
\text { students }\end{array}$} & \multirow{2}{*}{$\begin{array}{l}\text { Arithmetic } \\
\text { mean }\end{array}$} & \multirow{2}{*}{$\begin{array}{l}\text { Standard } \\
\text { deviation }\end{array}$} & \multirow{2}{*}{$\begin{array}{l}\text { Degree of } \\
\text { freedom }\end{array}$} & \multicolumn{2}{|c|}{ T-Value } & \multirow{2}{*}{$\begin{array}{c}\text { Function } \\
\text { level }\end{array}$} \\
\hline & & & & & Tabular & $\begin{array}{c}\text { Calculate } \\
\text { d }\end{array}$ & \\
\hline Pre-test & 30 & 27,966 & 8,356 & 29 & 15,746 & 2,042 & $\begin{array}{l}\text { Post-test } \\
\text { functional }\end{array}$ \\
\hline Post-test & 30 & 69,900 & 9,721 & & & & \\
\hline
\end{tabular}

\section{Interpretation of results:}

In light of the research findings, this can be attributed to the following:

1- The steps of the realistic model and its four sequential stages have contributed to the formation and development of the students 'mental structure by linking new information with previous experiences and applying them in educational situations, solving problems based on speculative foundations searching for reasons and introductions. Thus, meaningful learning has been achieved through the high level of achievement of students of the experimental group and the development of critical thinking in them compared to the level of students of the control group.

3- The learning process is cumulative and continuous, depending on the students 'cognitive maturity level. Therefore, it is necessary to adopt the preparatory phase in applying the principles of realistic constructive knowledge that includes the students' background knowledge, which contributed to the consolidation of some historical concepts and correcting the wrong ones.

\section{Conclusions:}

1- Raising the academic achievement of female students of literary fifth class in history

2- Developing critical thinking among the literary fifth female students.

\section{Recommendations:}

1- Adopting the realistic model in teaching middle school students.

2- Include cognitive and constructive models and strategies, including the realistic model and the stages of its implementation, in the curriculum of the teaching methods course in educational colleges.
3- Increasing teachers 'awareness of modern theories and models in secondary teaching in particular, by holding seminars and training courses.

4- Training students to adopt the method of critical thinking, by linking the course material to educational situations that teach it within the external environment.

\section{References}

1. Ibrahim, MagdyA. (2004). Learning Strategies and Learning Styles. Edition 1, The Anglo-Egyptian Library.

2. Abu Jadu, S.M,A (2000). Educational Psychology. 2nd Edition, Dar Al Masirah, Amman.

3. Muhammad, B. N. (2007). Teaching theoretical and practical thinking. 1st Edition, Dar Al Masirah, Amman.

4. Al-Khazraji, A, H. J. (2011). Building a program according to information-processing strategies and its effect on achievement and cognitive preference among students of the College of Education and the development of their critical thinking. (unpublished $\mathrm{PhD}$ thesis), University of Baghdad Ibn Al-Haytham College of Education, Baghdad.

5. Al-Khalili, K,Y and et al. (1995). Concepts of Public Sciences and Health in the First Four Grades", Textbook Press, Sana'a.

6. (1996). Teaching Science in the General Education Stages", 1st floor, Dar Al Qalam, Dubai.

7. AzZand, W.K. (2004). Educational designs, Special Education Academy, Riyadh.

8. Shehata, H. and Zainab A. (2003). Glossary of educational and psychological terms, Cairo Library, Cairo.

9. Abd al-Rahman, A, H. and Adnan H.Zangana (2007). Methodological patterns and their 
applications in the human sciences, Al-Wefaq Company Press, Baghdad.

10. Abdul Redha, Muhammad, and Batoul Khalil Faris (2006). The effect of using a realistic model to learn the acquisition of concepts on academic achievement and the development of scientific trends among students of the Teacher Education Institute, Journal of Educational and Psychological Sciences, College of Arts, Baghdad.

11. Al-Atoum, A, Y. (2004). Development of thinking skills, theoretical models and practical applications, 2nd ed., Dar Al Masirah, Amman.

12. Attia, M. A. (2010). Al Kafi in Teaching Methods of the Arabic Language, Dar Al Shorouk, Amman.

13. Odeh, A,S., and Khalil Yusef al-Khalili (1988). Statistics Researcher in Education and Human Sciences, Thought Library, Amman.

14. Al-Falih, M, M. (2003). The effectiveness of the realistic model in developing academic achievement and science processes and modifying understanding, error, and direction towards science among firstgrade intermediate students, King Fahd University, Kingdom of Saudi Arabia, Riyadh.

15. Muhammad, UdayKhaled (2009). Knowledge of the realistic model in modifying the understanding and error of the physical concepts of second-grade female students and their academic achievement, University of Babylon, College of Basic Education, an unpublished master thesis.

16. Al-Nabhan, M. (2004). Basics of measurement in behavioral sciences, Dar Al-Shorouk, Amman.

17. Ministry of Education, Republic of Iraq (1998). Middle School Curriculum, General Directorate of Curricula. 